\title{
'Omic diagnostics trip up on way to clinic
}

As two diagnostics companies learned recently at their expense, the FDA is taking a hard look at gene and protein expression-based tests. Perhaps harder than some developers had hoped, after another kind of 'omic test, based on genetic variation, first received approval in late 2004. For now, diagnostics companies developing expression-based tests are expected to follow the same regulatory pathway, even though they have yet to prove those tests are dependable enough to be used as clinical diagnostics.

Dutch company Agendia of Amsterdam learned in early April 2004 from the Rockville, Maryland-based US Food and Drug Administration (FDA) that the company's 70-gene expression chip "may not be in conformance" with FDA regulations. Its US partner, the Molecular Profiling Institute in Phoenix, Arizona, had just launched Agendia's chip as a prognostic test for breast cancer in the US, under the trade name MammaPrint. 윽 Meanwhile, in February 2004, the FDA sent a similar notice to the makers of a proteomicsbased ovarian cancer detection test, known as OvaCheck. Bethesda, Maryland-based Correlogic Systems, which developed that test, was hoping to launch it in the first quarter of 2004.

Officials cannot comment on either case until they are resolved, according to Steven Gutman, director of the FDA's Office of In Vitro Diagnostic Device Evaluation and Safety. Recent history, however, suggests FDA is making sure 'omic tests get special attention-thus explaining the delays in approval-because of their complexity and novelty. "Genomic and proteomic tests raise a number of challenges," says Gutman, "but it is possible for these products to reach the market smoothly."

As evidence, Guttman points to Roche Diagnostic's AmpliChip CYP450, the first

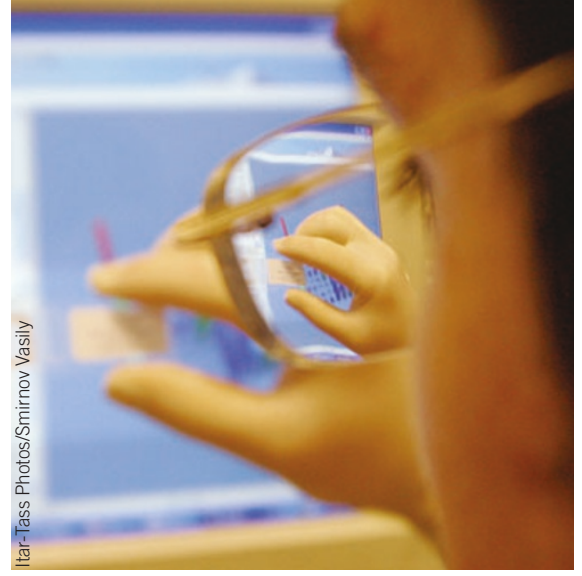

Gene expression tests seem to be slower to get through regulatory approval than their counterparts based on gene variation.

FDA-approved DNA microarray test (Nat. Biotechnol. 21, 959-960, 2003). The agency determined, that a microarray is too complex and novel to be approved through the light regulatory path chosen by Roche; that of an analyte-specific reagent. The company had to take a slightly tougher path for devices requiring more data (known as $510 \mathrm{~K}$ ), that is still less stringent than a full-blown premarket application (PMA).

In the end, "Some people were surprised at how quickly it was cleared," says Silvia Cerqueira, a clinical diagnostic research analyst at Frost \& Sullivan of San Antonio, Texas. Soon after AmpliChip was approved, Tm Bioscience of Toronto, Ontario, received approval along the same regulatory path for another test measuring genetic variation (used for cystic fibrosis). This class of 'omic tests is moving toward the market more quickly than those measuring gene and protein expression, because the results are "black and white," says Greg Hines, CEO of Tm Bioscience (see Table 1). Expression tests, meanwhile, must measure relative levels of many genes or proteins, which is much harder to reproduce.

One way developers may be able to sidestep the reproducibility problem is by incorporating genomic data into more dependable traditional tests. For example, Genomic Health of Redwood City, California, has set the standard here, turning a 21-gene signature expression test into a technology trusted by clinicians: a reverse transcriptase-polymerase chain reaction (RT-PCR)-based assay. "Except for Genomic Health's [tests], these trials are usually not very convincing," says Larry Norton, who heads up the breast cancer programs at New York's Memorial Sloan-Kettering.

Another major block on the road to bringing expression tests to the market is their level of acceptance in clinical setting. Expression chips are extremely popular as discovery tools; however, they are still facing tremendous skepticism in the clinic. "The Zeitgeist is that expression arrays are not reliable for predicting individual cases," says Norton. To increase acceptance in the clinic, expression test developers will have to face the same challenge as all 'omic test developers: to find platforms that are reliable enough for clinical use.

Chip-based expression tests should be able to follow the same path to market as variation tests have taken, says diagnostic consultant Ken Rubenstein of Santa Barbara, California. "Their success here is likely to rest upon the FDA's level of comfort with the particular technology platform used, and whether the test measures something that is immediately critical to the patient's life or death."

Malorye A. Branca, Boston
Table 1 New and emerging 'omic tests

\begin{tabular}{|c|c|c|}
\hline Maker & Product & Approval status \\
\hline Agendia & MammaPrint & Pending at FDA \\
\hline Correlogic Systems & OvaCheck & Pending at FDA \\
\hline $\begin{array}{l}\text { Exagen } \\
\text { (Albuquerque, NM) }\end{array}$ & $\begin{array}{l}\text { Breast cancer } \\
\text { prognosis test }\end{array}$ & $\begin{array}{l}\text { Submission to FDA for PMA anticipated by } \\
\text { end of } 2005\end{array}$ \\
\hline Genomic Health & Oncotype Dx & $\begin{array}{l}\text { Not an FDA-regulated product. Launched as a } \\
\text { laboratory-developed test in California, January } 2004\end{array}$ \\
\hline Roche & Leukemia array & Launch anticipated 2006-2007 \\
\hline Tm Bioscience & $\begin{array}{l}\text { Ashkenazi Jewish } \\
\text { Panel }\end{array}$ & $\begin{array}{l}\text { Launched as analyte-specific reagent in } \\
\text { June 2005, FDA-approved test anticipated in } 2006\end{array}$ \\
\hline
\end{tabular}

Characteristics

A 70-gene expression signature, measured on an Agilent DNA microarray, predicts prognosis for certain breast cancer patients

Protein expression pattern analysis. More than 150,000 starting data points are reduced to $5-10$ for finallevaluation

Traditional FISH test, derived from gene expression as well as other data.

A 21-gene expression assay done using RT-PCR for prognosis in breast cancer.

A 300-gene expression microarray test.

Tests 61 alleles in 8 genes, related to neurological

diseases; uses same platform as cystic fibrosis test. 